\title{
TANGGUNG JAWAB KONSULTAN DALAM PEMBUATAN ANALISIS MENGENAI DAMPAK LINGKUNGAN (AMDAL) DI PROVINSI KEPULAUAN BANGKA BELITUNG
}

Oleh:

\author{
Yokotani, S.H., M.H., Reko Dwi Salfutra, S.H., M.H., dan Wirazilmustaan, S.H., M.H.* \\ Abstract
}

The purposes of this research are: first, to identify and analyze the arrangement of the consultant responsibilities in making the AMDAL in Indonesia; second, to analyze and criticize the implementation of the consultant responsibilities in making the AMDAL in Bangka Belitung. Based on these purposes, so the issues that have been discussed are: first, how the arrangement of the consultant responsibilities in making the AMDAL in Indonesia?; second, how the implementation of the consultant responsibilities in making the AMDAL in Bangka Belitung?. To discuss these issues, conducted empirical legal research with the type of research the effectiveness of the law. This research proved, that: first, the consultant responsibilities in making the AMDAL regulated by the Act Number 32 of 2009 years, and the Environment Minister Regulation Number 7 of 2010 years; second, the consultant responsibilities in makin AMDAL will be completed to the extent of agreement with the proponent. Therefore, the recommendations of this research are: first, needed to optimize the enforcement of the Act Number 32 of 2009 years, and the Environment Minister Regulation Number 7 of 2010 years; second, needed more specifically regulation concerning the recognition in makin the AMDAL document.

Keywords: Responsibility, consultant, AMDAL, and environment

\section{A. PENDAHULUAN}

Pancasila $^{1}$ merupakan satu kesatuan yang bulat dan utuh yang memberikan keyakinan dan kepercayaan kepada masyarakat Indonesia, bahwa kebahagiaan hidup akan tercapai, jika didasarkan atas keselarasan, keserasian dan keseimbangan, baik dalam hubungan manusia dengan

*Dosen Tetap Fakultas Hukum Universitas Bangka Belitung.

${ }^{1}$ Pancasila sebagai dasar, ideologi dan falsafah hidup bangsa Indonesia (Staatfundamental Norm).
Tuhan Yang Maha Esa sebagai makhluk ciptaan-Nya, maupun manusia dengan alam dan manusia sebagai pribadi (personal) dalam rangka mencapai suatu kemajuan lahir maupun kebahagiaan batin. Antara manusia, masyarakat dan lingkungan terdapat hubungan timbal balik yang selalu harus dibina dan dikembangkan agar dapat tetap dalam keselarasan, keserasian dan keseimbangan yang dinamis. 
Undang-Undang Dasar Negara Republik Indonesia Tahun 1945 sebagai landasan konstitusional melalui ketentuan Pasal 33 ayat (3) telah mewajibkan agar penggunaan sumber daya alam dan ekosistemnya dipergunakan untuk sebesarbesarnya kemakmuran rakyat. Konstitusi Negara Republik Indonesia tersebut memberikan perlindungan tertinggi kepada setiap rakyat Indonesia dalam menikmati kekayaan alam yang terkandung di dalamnya untuk dikuasai oleh negara dan dipergunakan sebesar-besarnya bagi kemakmuran rakyat, "bumi dan air dan kekayaan alam yang terkandung di dalamnya dikuasai oleh negara dan dipergunakan untuk sebesar-besarnya kemakmuran rakyat".

Sehubungan dengan itu, dalam kaitannya dengan pemanfaatan sumber daya alam berupa lingkungan hidup seiring dengan perkembangan zaman yang membutuhkan sumber daya alam dalam artian pembangunan, maka dampak yang timbul tidak selamanya baik dan bermanfaat bagi manusia, malahan dapat membahayakan kehidupan manusia. Pembangunan memanfaatkan secara terusmenerus sumber daya alam guna meningkatkan kesejahteraan dan mutu hidup masyarakat. Sementara itu, ketersediaan sumber daya alam sangat terbatas dan tidak merata, baik dalam segi kuantitas maupun dalam segi kualitasnya, sedangkan permintaan akan sumber daya alam tersebut makin meningkat sebagai akibat meningkatnya kegiatan pembangunan untuk memenuhi kebutuhan penduduk yang meningkat dan beragam.

Memasuki era globalisasi yang penuh ketidakpastian telah merubah lingkungan yang tenang, mudah diramalkan dan sederhana menjadi bergejolak, sukar diramalkan dan kompleks. Untuk menghadapi globalisasi tersebut, diperlukan kemandirian dan partisipasi serta kerja sama. Seiring dengan perkembangan pembangunan, konsep pembangunan yang dibutuhkan untuk menghadapi globalisasi di dalam upaya perlindungan kawasan lingkungan hidup adalah "pembangunan yang tidak mempertentangkan pertumbuhan dan pemerataan atau konsep yang bertumpu pada pemberdayaan dan partisipasi masyarakat atau yang sering disebut dengan konsep pembangunan berkelanjutan (sustainable development)". ${ }^{2}$ Di dalam konsep ini, "masyarakat memiliki

\footnotetext{
${ }^{2}$ Agenda 21 Sektoral,Agenda ENERGI Untuk Pembangunan Kualitas Hidup Secara Berkelanjutan,Proyek Agenda 21 Sektoral Kerjasama Kantor Menteri Negara Lingkungan Hidup dengan UNDP, Jakarta, 2000, hlm. 11.
} 
hak untuk berpasrtisipasi dalam pengambilan keputusan, pembuatan kebijakan, perencanaan, pelaksanaan, evaluasi dan kontrol".3

Sesuai dengan itu, menurut Addinul Yakin menyatakan, bahwa "proses pembangunan yang menitikberatkan pada pertumbuhan sering bertentangan dengan prinsip pelestarian dan perlindungan lingkungan, sehingga sering dikatakan bahwa antara pembangunan dan lingkungan terkesan kontradiktif". ${ }^{4}$ Tetapi hal ini tidaklah selalu benar, karena dua kepentingan ini bisa saling berinteraksi atau diintegrasikan, sehingga kepentingan pembangunan dan lingkungan bisa samasama tercapai. Akibat kuatnya saling interaksi dan ketergantungan antara dua faktor tersebut, diperlukan pendekatan yang cocok bagi kepentingan pembangunan berkelanjutan atau pembangunan berwawasan lingkungan (sustainable development). Sesuai dengan itu, menurut Ginandjar Kartasasmita menyatakan, bahwa "dalam kata pembangunan, hal yang sangat pokok yaitu adanya hakikat membangun, yang

\footnotetext{
${ }^{3}$ Ibid., hlm. 146.

${ }^{4}$ Addinul Yakin, Ekonomi Sumber Daya dan Lingkungan, Teori dun Kebijaksanaan Pembangunan Berkelanjutan, Jakarta Akademika Presindo, Jakarta, 1997, hlm. 11.
}

berlawanan dengan merusak". 5 Oleh karena itu, perubahan ke arah keadaan yang lebih baik seperti yang diinginkan dan dengan upaya yang terencana, harus dilakukan melalui jalan yang tidak merusak, tetapi justru mengoptimalkan sumber daya yang tersedia dan mengembangkan potensi yang ada.

Penyelenggaraan pengelolaan kawasan lingkungan hidup dalam rangka pembangunan berkelanjutan yang berwawasan pelestarian lingkungan termasuk ekosistemnya harus didasarkan kepada instrumen hukum dengan memperhatikan tingkat kesadaran masyarakat dan perkembangan lingkungan global,karena unsur-unsur sumber daya hayati dan ekosistemnya saling bergantung antara satu dengan lainnya, dan pemanfaatannya akan saling mempengaruhi, sehingga "kerusakan dan kepunahan salah satu daripadanya akan berakibat terganggunya ekosistem, maka diperlukan suatu pengaturan pemanfaatannya dan perlindungan ekosistemnya". 6

\footnotetext{
${ }^{5}$ Ginandjar Kartasasmita,Administrasi Pembangunan: Perkembangan Pemikiran dan Praktiknya di Indonesia,Pustaka LP3ES, Jakarta, 1997, hlm. 9.

${ }^{6}$ Salim, H.S.,Dasar-Dasar Hukum Keluitanan, Edisi Revisi, Sinar Grafika, Jakarta, hlm.8-11.
} 
Oleh sebab itu, dalam rangka mewujudkan pembangunan berkelanjutan yang berwawasan lingkungan seiring dengan pembangun di bidang lingkungan harus adanya langkah sinergis dan strategis. Adapun salah satu langkah stategis yang dapat dilakukan tersebut adalah "dengan adanya pembuatan Analisis Mengenai Dampak Lingkungan (AMDAL)". 7 Dengan adanya Analisis Mengenai Dampak Lingkungan (AMDAL) terhadap suatu proses pembangunan, maka diharapkan dapat meminimalisirkan dampak dari kerusakan lingkungan dari setiap tindakan pembangunan itu sendiri.

Ketentuan Pasal 1 angka 11 UndangUndang Nomor 32 Tahun 2009 Tentang Perlindungan dan Pengelolaan Lingkungan Hidup menentukan, bahwa:

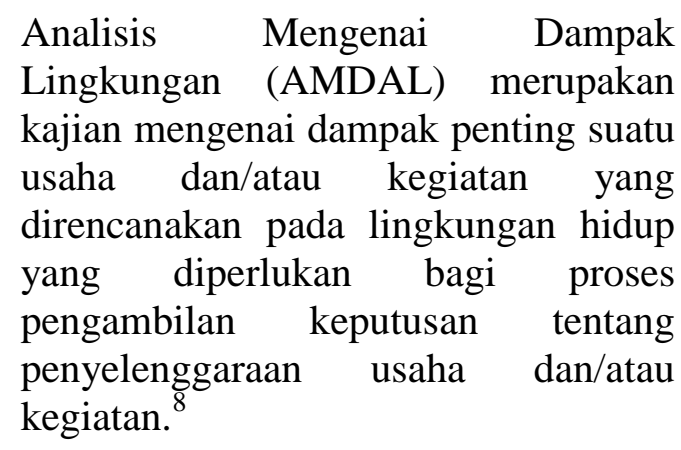

\footnotetext{
${ }^{7}$ M. Saifudin, "Tanggung Jawab Konsultan AMDAL dalam Pembuatan Analisis Mengenai Dampak Lingkungan", Makalah, Fakultas Hukum Universitas Mulawarman, 2013, hlm. 1.

${ }^{8}$ Periksa Pasal 1 angka 11 Undang-Undang Nomor 32 Tahun 2009 Tentang Perlindungan dan Pengelolaan Lingkungan Hidup yang diundangkan dalam Lembaran Negara Republik Indonesia Tahun
}

Berdasarkan ketentuan tersebut di atas, dapat dipahami bahwa secara yuridis, analisis mengenai dampak lingkungan dibutuhkan hanya terhadap kegiatan pembangunan yang berdampak penting. Akan tetapi, formulasi hukum tidak secara jelas memberikan batas, baik secara kuantitatif maupun kualitatif tentang apa yang merupakan dampak yang penting. Secara yuridis, hanya menyatakan dampak penting itu berupa perubahan lingkungan, yaitu yang sangat mendasar bersumber dari suatu kegiatan.

Sehubungan dengan itu, berdasarkan ketentuan Peraturan Menteri Lingkungan Hidup Nomor 16 Tahun 2012 Tentang Penyusunan Dokumen Lingkungan Hidup menentukan, bahwa lembaga penyedia jasa penyusun dokumen Analisis Mengenai Dampak Lingkungan (AMDAL) adalah badan hukum yang bergerak dalam bidang jasa penyusunan dokumen Analisis Mengenai Dampak Lingkungan (AMDAL). Setiap penyedia jasa pembuatan dokumen Analisis Mengenai Dampak Lingkungan (AMDAL), yaitu konsultan hukum dokumen Analisis Mengenai Dampak Lingkungan (AMDAL) tidak boleh membuat suatu dokumen 2009 Nomor 140, Tambahan Lembaran Negara Republik Indonesia Nomor 5059. 
Analisis Mengenai Dampak Lingkungan (AMDAL) yang menyimpang dari ketentuan peraturan perundang-undangan. Artinya, bahwa setiap konsultan hukum memiliki peranan yang sangat strategis dalam pembuatan suatu dokumen Analisis Mengenai Dampak Lingkungan (AMDAL). Oleh sebab itu, secara yuridis setiap konsultan hukum memiliki tanggung jawab atas semua keterangan yang diberikan dalam pembuatan dokumen Analisis Mengenai Dampak Lingkungan (AMDAL). Akan tetapi, dalam realita sehari-hari, keterangan dari konsultan hukum yang membuat dokumen Analisis Mengenai Dampak Lingkungan (AMDAL) seringkali melenceng dari apa yang telah diprediksikannya dalam dokumen Analisis Mengenai Dampak Lingkungan (AMDAL). Sehingga, suatu kegiatan pembangunan yang sebenarnya telah dibuatkannya dokumen Analisis Mengenai Dampak Lingkungan (AMDAL) yang berfungsi untuk meminimalisirkan potensi terjadinya pencemaran terhadap lingkungan, malah dalam realitanya sangat kontradiktif. Permasalahan mengenai dokumen Analisis Mengenai Dampak Lingkungan (AMDAL) ini pun terjadi di Provinsi Kepulauan Bangka Belitung, salah satunya terjadi di Kabupaten Bangka
Tengah Provinsi Kepulauan Bangka Belitung, di mana masyarakat mempertanyakan pembuatan dokumen Analisis Mengenai Dampak Lingkungan (AMDAL) yang dilakukan oleh konsultan, karena "masyarakat di daerah tersebut merasa tidak dilibatkan di dalam perumusannya". 9 Bahkan, konsultan hukum yang membuat dokumen Analisis Mengenai Dampak Lingkungan (AMDAL) seakan lari dari tanggung jawab atas terjadinya suatu pencemaran lingkungan akibat suatu kegiatan pembangunan yang telah ia buat dokumen Analisis Mengenai Dampak Lingkungannya.

Oleh sebab itu, diperlukan suatu bentuk peran aktif dari pemerintah untuk mengantisipasi setiap permasalahan hukum di atas. Hal ini sesuai dengan ketentuan Pasal 3 Undang-Undang Nomor 32 Tahun 2009 Tentang Perlindungan dan Pengelolaan Lingkungan Hidup yang menentukan, bahwa:

a. melindungi wilayah Negara Kesatuan Republik Indonesia dari pencemaran dan/atau kerusakan lingkungan hidup;

b. menjamin keselamatan, kesehatan, dan kehidupan manusia;

\footnotetext{
${ }^{9}$ Ahmadi, "Walhi Babel Soroti Amdal Penambangan Pasir Kuasa", http://m.antarababel.com/berita/9847/walhibabelsor otiamdalpenambanganpasirkuarsa, diakses pada hari Jum'at tanggal 24 April 2015 pukul 21:00 wib.
} 
c. menjamin kelangsungan kehidupan makhluk hidup dan kelestarian ekosistem;

d. menjaga kelestarian fungsi lingkungan hidup;

e. mencapai keserasian, keselarasan, dan keseimbangan lingkungan hidup;

f. menjamin terpenuhinya keadilan generasi masa kini dan generasi masa depan;

g. menjamin pemenuhan dan perlindungan hak atas lingkungan hidup sebagai bagian dari hak asasi manusia;

h. mengendalikan pemanfaatan sumber daya alam secara bijaksana;

i. mewujudkan pembangunan berkelanjutan; dan

j. mengantisipasi isu lingkungan global. $^{10}$

Penegakan hukum harus dijalankan berdasarkan peraturan perundang undangan yang berlaku. Dasar hukum digunakan sebagai "rujukan dan alasan mengapa dan bagaimana suatu pelanggaran telah terjadi", ${ }^{11}$ sehingga akan diketahui jalur hukum serta prosedur yang akan dilalui di dalam penegakan hukum sebagai upaya perlindungan dan pengelolaan lingkungan hidup ke depan yang lebih terarah dan lebih baik.

\footnotetext{
${ }^{10}$ Periksa Pasal 3 Undang-Undang Nomor 32 Tahun 2009 Tentang Perlindungan dan Pengelolaan Lingkungan Hidup yang diundangkan dalam Lembaran Negara Republik Indonesia Tahun 2009 Nomor 140, Tambahan Lembaran Negara Republik Indonesia Nomor 5059.

${ }^{11}$ Haerudin R. Sadjudin,Panduan Penegakan Hukum dalam penyelamatan Hutan, Inform (Indonesia Forest and Media), Jakarta, hlm. 4.
}

Dari latar belakang diatas dapat dibuat beberapa rumusan masalah yaitu

1. Bagaimana pengaturan tanggung jawab konsultan dalam pembuatan analisis mengenai dampak lingkungan dalam perspektif peraturan perundangundangan di Indonesia?

2. Bagaimana implementasi tanggung jawab konsultan dalam pembuatan analisis mengenai dampak lingkungan di Provinsi Kepulauan Bangka Belitung?

\section{B. PEMBAHASAN}

\section{Pengaturan Tanggung Jawab} Konsultan dalam Pembuatan AMDAL

Lingkungan hidup merupakan anugerah dari Tuhan Yang Maha Esa, di mana didalamnya manusia menjalankan berbagai aktifitas, berinteraksi dengan komponenkomponen lain yang ada guna mempertahankan kelangsungan hidupnya. Semula, lingkungan hidup tersebut merupakan lingkungan yang memang sudah ada secara ilmiah, akan tetapi dalam perkembangannya manusia melakukan berbagai macam perubahan sehingga menimbulkan kondisi lingkungan yang baru. 
Kemampuan manusia untuk merubah lingkungan dan menimbulkan hal-hal baru tersebut turut mempengaruhi keseimbangan lingkungan hidup. Apabila keseimbangan lingkungan tersebut terganggu, dikhawatirkan akan menimbulkan reaksi balik dari lingkungan yang kemudian dapat menimbulkan bencana.

Indonesia adalah negara yang kaya dengan sumber daya alam. Hal ini merupakan salah satu modal untuk melaksanakan pembangunan yang bertujuan untuk meningkatkan kesejahteraan rakyat. Akan tetapi, sumber daya alam adalah sesuatu yang terbatas, sementara pertumbuhan penduduk yang membutuhkan ketersediaan lingkungan tidak sebanding dengan ketersediaan lingkungan itu sendiri.

Sepanjang manusia berusaha berusaha memenuhi kebutuhan hidup dengan tidak memikirkan cara untuk menjaga keselamatan dan keseimbangan lingkungan hidup, maka permasalahan lingkungan hidup akan terus muncul dan membahayakan. Apabila proses pencemaran lingkungan hidup tersebut dibiarkan secara terus menerus akan mengakibatkan kerugian yang sangat besar bagi semua pihak. Salah satu kebutuhan manusia yang pemenuhannya bersinggungan dengan lingkungan hidup adalah kebutuhan ekonomi. Sebagai bentuk upaya untuk memenuhi kebutuhan ini, masyarakat melakukan berbagai macam kegiatan, termasuk mendirikan ins $=$ dustriindustri yang mengolah sumber daya alam sebagai bahan baku.

Pendirian industri diawali dengan pembukaan lahan yang merupakan kawasan lingkungan untuk dijadikan wilayah industri dan wilayah budidaya tanaman tertentu. Dalam proses pembukaan lahan seringkali menimbulkan perubahan terhadap kondisi ideal lingkungan, bahkan dalam operasionalnya industri yang didirikan juga dapat menimbulkan dampak negatif bagi lingkungan, seperti pencemaran lingkungan karena limbah buangannya.

Oleh sebab itu, dalam upaya menekan atau meminimalkan dampak negatif akibat kegiatan yang mungkin terjadi terhadap lingkungan sebagai bentuk perlindungan dan pengelolaan lingkungan hidup, maka diperlukan suatu bentuk pembinaan bagi setiap kegiatan yang menyangkut ekploitasi 
sumber daya alam dan berpotensi untuk menimbulkan dampak negatif bagi lingkungan hidup agar penurunan akibat eksploitasi diimbangi dengan pemeliharaan lingkungan itu sendiri serta diperlukan suatu bentuk kajian yang baik dan benar tentang dampakdampak yang mungkin dapat diminimalkan akibat aktivitas eksploitasi sumber daya alam tersebut.

Menurut Emil Salim menyatakan, bahwa "adapun perlindungan dan pengelolaan lingkungan hidup tersebut memiliki ruang lingkup mulai dari perencanaan, pemanfaatan, pengendalian, pemeliharaan, pengawasan, dan penegakan hukum". ${ }^{12}$ Dengan demikian, konsep pembangunan yang berkelanjutan terhadap pengelolaan lingkungan hidup dapat dilaksanakan sebagaimana amanatk ketentuan Pasal 1 angka 3 Undang-Undang Nomor 32 Tahun 2009 Tentang Perlindungan dan Pengelolaan Lingkungan Hidup, menentukan bahwa:

Pembangunan berkelanjutan adalah upaya sadar dan terencana yang memadukan aspek

${ }^{12}$ Emil Salim, Ratusan Bangsa Merusak Satu Bumi, Penerbit Buku Kompas, Jakarta, 2010, hlm. 45. lingkungan hidup, sosial, dan ekonomi ke dalam strategi pembangunan untuk menjamin keutuhan lingkungan hidup serta keselamatan, kemampuan, kesejahteraan, dan mutu hidup generasi masa kini dan generasi masa depan.

Berdasarkan ketentuan tersebut di atas, dipahami bahwa pembangunan berkelanjutan merupakan upaya sadar dan terencana dalam rangka mengelola dan memanfaatkan sumber daya alam untuk mencapai tujuan pembangunan, yakni meningkatkan kualitas kehidupan masyarakat dan bangsa Indonesia. Pembangunan tersebut dari masa ke masa terus berlanjut dan berkesinambungan serta selalu ditingkatkan pelaksanaannya, sehingga pada akhirnya dapat berguna dalam memenuhi dan meningkatkan kebutuhan penduduk.

Pelaksanaan pembangunan sebagai kegiatan yang berkesinambungan dan selalu meningkat seiring dengan baik dan meningkatnya jumlah dan kebutuhan penduduk, menarik serta mengundang resiko pencemaran dan perusakan yang disebabkan oleh tekanan kebutuhan pembangunan terhadap sumber daya alam, tekanan yang semakin besar 
tersebut ada dan dapat mengganggu, merusak struktur dan fungsi dasar ekosistem yang menjadi penunjang kehidupan.

Sebagai bentuk upaya dalam rangka mencegah kemerosotan lingkungan dan sumber daya alam dengan maksud agar lingkungan dan sumber daya alam tersebut tetap terpelihara keberadaan dan kemampuan dalam mendukung berlanjutnya pembangunan, maka setiap aktivitas pembangunan haruslah dilandasi oleh dasar-dasar pertimbangan pelestarian dan perlindungan akan sumber daya alam itu sendiri.

Sesuai dengan itu, Provinsi Kepulauan Bangka Belitung sebagai salah satu daerah pemekaran dengan sejumlah industri yang ada, terutama yang menyangkut masalah pertambangan, harus mampu untuk membangun daerahnya ke arah yang lebih baik dengan tetap mempertahankan kondisi lingkungan yang baik. Namun demikian, dalam perjalanan pembangunan di Provinsi Kepulauan Bangka Belitung tersebut, terdapat permasalahan-permasalahan yang harus ditangani secara benar sesuai apa yang diamanatkan oleh
Undang-Undang Nomor 32 Tahun 2009 tentang Perlindungan dan Pengelolaan Lingkungan Hidup, seperti pembuatan terhadap dokumen Analisis Mengenai Dampak Lingkungan (AMDAL) yang diharapkan dapat menjadi kajian yang komprehensif dalam rangka meminimalkan dampakdampak dari suatu kegiatan pembangunan.

Berdasarkan ketentuan Pasal 1 angka 11 Undang-Undang Nomor 32 Tahun 2009 tentang Perlindungan dan Pengelolaan Lingkungan Hidup, ditentukan bahwa Analisis Mengenai Dampak Lingkungan (AMDAL) adalah "kajian mengenai dampak penting suatu usaha dan/atau kegiatan yang direncanakan pada lingkungan hidup yang diperlukan bagi proses pengambilan keputusan tentang penyelenggaraan usaha dan/atau kegiatan". Sesuai dengan itu, menurut Daud Silalahi menyatakan, bahwa:

Keinginan untuk mempengaruhi pengaruh negatif dan resiko pada tingkat yang mungkin (Risk Assesment) dan mengelola resikonya (Risk Management) melalui mekanisme dan sistem hukum lingkungan dalam apa yang disebut sebagai Analisis 
Mengenai Dampak Lingkungan (AMDAL)". ${ }^{13}$

Atas dasar pemikiran di atas, dipahami bahwa Analisis Mengenai Dampak Lingkungan (AMDAL) merupakan suatu bentuk dokumen analisis yang sangat penting untuk disusun sehubungan dengan pemanfaatan sumber daya lingkungan hidup, seperti:

1. Analisis Mengenai Dampak Lingkungan (AMDAL) akan membantu memberikan uraian keterkaitan perundangundangan dan pelaksanaan Analisis Mengenai Dampak Lingkungan (AMDAL) dengan undang-undang atau ketentuan hukum sektoral untuk memperoleh persamaan persepsi dan penafsiran atas hukum yang mengatur pelaksanaan Analisis Mengenai Dampak Lingkungan (AMDAL) dilihat dari penyusunan, penilaian, dan pengambilan keputusan.

2. Pengaruh dari kualifikasi Analisis Mengenai Dampak Lingkungan (AMDAL) oleh perangkat aparatur pemerintah yang memiliki kriteria keahlian khusus dalam proses Analisis Mengenai Dampak Lingkungan (AMDAL) sebagai penanggung jawab utama. Status AMDAL dalam proses pengambilan

\footnotetext{
${ }^{13}$ Daud Silalahi, Hukum Lingkungan dalam Sistem Penegakan Hukum Lingkungan Indonesia, Alumni, Bandung, 2001, hlm. 1.
}

keputusan sebagai Significant Agency Expertise yang memegang yurisdiksi kewenangan dan merupakan ruang lingkupnya yang lebih utama dalam masalah hukum yang timbul di kemudian hari. ${ }^{14}$

Sehubungan dengan hal tersebut di atas, untuk menciptakan suatu pembangunan yang berkesinambungan, faktor lingkungan hidup menjadi perhatian yang utama. Oleh karena itu pembangunan yang memungkinkan timbulnya dampak penting terhadap lingkungan harus dibuat Analisis Mengenai Dampak Lingkungan (AMDAL). Kewajiban membuat Analisis Mengenai Dampak Lingkungan didasarkan pada Pasal 22 Undang-Undang Nomor 32 Tahun 2009 tentang Perlindungan dan Pengelolaan Lingkungan Hidup yang menentukan, bahwa "setiap usaha dan/atau kegiatan yang berdampak penting terhadap lingkungan hidup wajib memiliki analisis mengenai dampak lingkungan".

Dampak penting di sini yang dimaksud adalah dampak yang terjadi

\footnotetext{
${ }^{14}$ Eri Triana Sari, Tanggungjawab Konsultan dalam Pembuatan Analisis Mengenai Dampak Lingkungan dan Akibat Hukumnya (Studi Kasus di CV. Daya Cipta Mandiri), FH Universitas Semarang, Semarang, 2009, hlm. 2.
} 
setelah pembangunan berjalan, tugas Konsultan membuat analisa sehingga dampak tersebut dapat diprediksi untuk selanjutnya ditemukan solusi sebagai bentuk upaya antisipasi. Sedangkan dampak penting di sini adalah dampak yang terjadi setelah pembangunan, di mana penanganannya dengan cara konsultan membuat analisa terhadap dampak tersebut, sehingga tidak merusak tatanan dari suatu kawasan lingkungan.

Sesuai dengan itu, ketentuan Pasal 22 Undang-Undang Nomor 32 Tahun 2009 tentang Perlindungan dan Pengelolaan Lingkungan Hidup tersebut di atas, pemerintah juga telah menetapkan Peraturan Pemerintah Nomor 27 Tahun 1999 tentang Analisis Mengenai Dampak Lingkungan. Peraturan Pemerintah ini merupakan tonggak sejarah yang amat penting dalam rangka pembangunan berwawasan lingkungan.

Pada pembuatan dokumen Analisis Mengenai Dampak Lingkungan (AMDAL), apabila Pemrakarsa merasa tidak mampu membuat sendiri, maka diperlukan kerjasama antara Pemrakarsa dengan badan hukum Konsultan. Hal ini sesuai dengan ketentuan Pasal 2 ayat (2) Peraturan Menteri Lingkungan Hidup Nomor 7 Tahun 2010 Tentang Sertifikasi Kompetensi Penyusun Dokumen Analisis Mengenai Dampak Lingkungan dan Persyaratan Lembaga Pelatihan Kompetensi Penyusun Dokumen Analisis Mengenai Dampak Lingkungan Hidup yang menentukan, bahwa:

Dalam penyusunan dokumen Analisis Mengenai Dampak Lingkungan (AMDAL) sebagaimana dimaksud pada ayat (1), pemrakarsa dapat meminta bantuan kepada lembaga penyedia jasa penyusunan dokumen Analisis Mengenai Dampak Lingkungan (AMDAL) yang telah mendapatkan tanda registrasi kompetensi.

Berdasarkan ketentuan di atas, diketahui bahwa tanggung jawab Konsultan diperlukan dalam pembuatan Analisis Mengenai Dampak Lingkungan (AMDAL). Semua proyek atau pembangunan dalam suatu lingkungan hidup dianalisis, yang diharapkan agar setiap kegiatan pembangunan tidak berdampak buruk pada lingkungan. Oleh sebab itu, melalui ketentuan Pasal 2 ayat (3) dan Pasal 3 Peraturan Menteri Lingkungan Hidup Nomor 7 Tahun 2010 Tentang 
Sertifikasi Kompetensi Penyusun

Dokumen Analisis Mengenai Dampak Lingkungan dan Persyaratan Lembaga Pelatihan Kompetensi Penyusun Dokumen Analisis Mengenai Dampak Lingkungan Hidup menentukan persyaratan-persyaratan yang harus dipenuhi bagi konsultan pembuat dokumen Analisis Mengenai Dampak Lingkungan (AMDAL). Pasal 2 ayat (3) Peraturan Menteri Lingkungan Hidup Nomor 7 Tahun 2010 Tentang Sertifikasi Kompetensi Penyusun Dokumen Analisis Mengenai Dampak Lingkungan dan Persyaratan Lembaga Pelatihan Kompetensi Penyusun Dokumen Analisis Mengenai Dampak Lingkungan Hidup menentukan, bahwa "penyusun dokumen Analisis Mengenai Dampak Lingkungan (AMDAL) sebagaimana dimaksud pada ayat (1) dan ayat (2) wajib memiliki sertifikat Kompentensi”. Lebih lanjut, dalam Pasal 3 Peraturan Menteri Lingkungan Hidup Nomor 7 Tahun 2010 Tentang Sertifikasi Kompetensi Penyusun Dokumen Analisis Mengenai Dampak Lingkungan dan Persyaratan Lembaga Pelatihan Kompetensi Penyusun Dokumen Analisis Mengenai Dampak
Lingkungan Hidup menentukan, bahwa:

Lembaga penyedia jasa penyusunan dokumen Analisis Mengenai Dampak Lingkungan (AMDAL) sebagaimana dimaksud dalam Pasal 2 ayat (3) wajib memenuhi persyaratan:

a. berbadan hukum;

b. memiliki paling sedikit 2 (dua) orang tenaga tetap penyusun dokumen Analisis Mengenai Dampak Lingkungan (AMDAL) yang memiliki sertifikat kompetensi dengan kualifikasi ketua tim penyusun dokumen Analisis Mengenai Dampak Lingkungan (AMDAL);

c. memiliki perjanjian kerja dengan tenaga tidak tetap penyusun dokumen Analisis Mengenai Dampak Lingkungan (AMDAL) yang memiliki sertifikat kompetensi penyusun dokumen Analisis Mengenai Dampak Lingkungan (AMDAL) dan seluruh personil yang terlibat dalam penyusunan dokumen Analisis Mengenai Dampak Lingkungan (AMDAL) yang dapat dipertanggungjawabkan secara hukum, termasuk dalam hal ketidakberpihakan;

d. memiliki sistem manajemen mutu; dan

e. melaksanakan pengendalian mutu internal terhadap pelaksanaanpenyusunan

dokumen Analisis Mengenai Dampak Lingkungan (AMDAL), termasuk menjaga prinsip ketidakberpihakan 
dan/atau menghindari konflik kepentingan.

Berdasarkan hal tersebut di atas, dipahami bahwa Konsultan pembuat Analisis Mengenai Dampak Lingkungan (AMDAL) bertanggung jawab atas semua data yang dibuatnya. Data yang dibuatnya tersebut adalah hasil Analisis Mengenai Dampak Lingkungan, yang laporannya berbentuk dokumen AMDAL. Oleh karena itu, seorang Konsultan tidak boleh menyimpang dari ketentuan di atas.

Sehubungan dengan itu, di dalam Kitab Undang-Undang Hukum Perdata mengenai tanggung jawab ini diatur dalam Pasal 1801 dan Pasal 1803 Kitab Undang-Undang Hukum Perdata. Pasal 1801 Kitab Undang-Undang Hukum Perdata menentukan, bahwa "Si kuasa tidak saja bertanggung jawab tentang perbuatan-perbuatan yang dilakukan dengan sengaja, tapi juga tentang kelalaian yang dilakukan dalam menjalankan kuasanya. Akan tetapi, tanggung jawab tentang kelalaian bagi seseorang yang dengan cuma-cuma menerima kuasa adalah tidak begitu berat, seperti yang dapat diminta dari seseorang yang untuk itu menerima upah”. Lebih lanjut, ketentuan Pasal 1803 Kitab Undang-Undang Hukum

Perdata menentukan, bahwa:

Penerima kuasa bertanggungjawab atas orang lain yang ditunjuknya sebagai penggantinyadalam melaksanakan kuasanya:

1. bila tidak diberikan kuasa untuk menunjuk orang lain sebagai penggantinya.

2. bila kuasa itu diberikan tanpa menyebutkan orang tertentu sedangkan orang yang dipilihnya ternyata orang yang tidak cakap atau tidak mampu. Pemberi kuasa senantiasa dianggap telah memberi kuasa kepada penerima kuasanya untuk menunjuk seorang lain sebagai penggantinya untuk mengurus barang-barang yang berada di luar wilayah Indonesia atau di luar pulau tempat tinggal pemberi kuasa. Pemberi kuasa dalam segala hal, dapat secara langsung mengajukan tuntutan kepada orang yang telah ditunjuk oleh penerima kuasa sebagai penggantinya.

\section{Implementasi Tanggung Jawab} Konsultan dalam Pembuatan AMDAL di Provinsi Kepulauan Bangka Belitung

Salah satu pihak yang berjasa dan bertanggungjawab dalam penyusunan laporan dokumen Analisis Mengenai Dampak Lingkungan (AMDAL) adalah 
konsultan. Dokumen yang telah disusun tersebut memuat kajian mengenai dampak penting dalam suatu usaha yang direncanakan pada lingkungan hidup untuk mengambil keputusan tentang penyelenggaraan usaha tersebut.

Setiap $\begin{array}{r}\text { perusahaan } \\ \text { haruslah }\end{array} \begin{array}{r}\text { sebagai } \\ \text { tidak }\end{array}$
pemrakarsa
sembarangan memilih konsultan
pembuat dokumen Analisis Mengenai
Dampak Lingkungan (AMDAL) atas
usaha atau kegiatan yang akan
dilakukannya. Di lain sisi, konsultan
pembuat dokumen Analisis Mengenai
Dampak Lingkungan (AMDAL) juga
harus memenuhi syarat-syarat ataupun
standar tertentu sebagai konsultan
pembuat Analisis Mengenai Dampak
Lingkungan (AMDAL) sebagaimana
yang diatur dalam peraturan perundang-undangan. Oleh sebab itu, pada tahun 2010, Kementerian Lingkungan Hidup mengeluarkan Peraturan Menteri Lingkungan Hidup Nomor 7 Tahun 2010 Tentang Sertifikasi Kompetensi Penyusun Dokumen Analisis Mengenai Dampak Lingkungan dan Persyaratan Lembaga Pelatihan Kompetensi Penyusun Dokumen Analisis Mengenai Dampak
Lingkungan Hidup, yang menentukan, bahwa:

Lembaga penyedia jasa penyusunan dokumen Analisis Mengenai Dampak Lingkungan (AMDAL) sebagaimana dimaksud dalam Pasal 2 ayat (3) wajib memenuhi persyaratan:

a. berbadan hukum;

b. memiliki paling sedikit 2 (dua) orang tenaga tetap penyusun dokumen Analisis Mengenai Dampak Lingkungan (AMDAL) yang memiliki sertifikat kompetensi dengan kualifikasi ketua tim penyusun dokumen Analisis Mengenai Dampak Lingkungan (AMDAL);

c. memiliki perjanjian kerja dengan tenaga tidak tetap penyusun dokumen Analisis Mengenai Dampak Lingkungan (AMDAL) yang memiliki sertifikat kompetensi penyusun dokumen Analisis Mengenai Dampak Lingkungan (AMDAL) dan seluruh personil yang terlibat dalam penyusunan dokumen Analisis Mengenai Dampak Lingkungan (AMDAL) yang dapat dipertanggungjawabkan secara hukum, termasuk dalam hal ketidakberpihakan;

d. memiliki sistem manajemen mutu; dan

e. melaksanakan pengendalian mutu internal terhadap pelaksanaanpenyusunan

dokumen Analisis Mengenai Dampak Lingkungan (AMDAL), termasuk menjaga prinsip ketidakberpihakan 
dan/atau menghindari konflik kepentingan.

Adapun syarat tersebut harus dipenuhi bagi setiap konsultan pembuat dokumen Analisis Mengenai Dampak Lingkungan (AMDAL), baik dalam pengertian konsultan yang berbentuk badan hukum maupun dalam bentuk perseorangan. Dengan terpenuhinya syarat-syarat tersebut di atas, maka setiap pemrakarsa dapat menggunakan jasa dari konsultan pembuat dokumen Analisis Mengenai Dampak Lingkungan (AMDAL) dengan cara mengeluarkan surat perintah kerja dalam pembuatan dokumen Analisis Mengenai Dampak Lingkungan (AMDAL).

Setelah pernyataan surat perintah kerja dari pihak Pemrakarsa kepada pihak konsultan pembuat dokumen Analisis Mengenai Dampak Lingkungan (AMDAL) beserta syaratsyarat lainnya, kemudian dilanjutkan pelaksanaan tugas-tugas yang harus dikerjakan bagi setiap konsultan pembuat dokumen Analisis Mengenai Dampak Lingkungan (AMDAL). Tugas-tugas Konsultan meliputi tugas pokok, tugas yang diperjanjikan, dan tugas yang sesuai dengan peraturan perundang-undangan yang berlaku.

Sehubungan dengan hal tersebut di atas, menurut Eddu Novandaharto menyatakan bahwa secara umum terdapat kewajiban-kewajiban dan hakhak konsultan pembuat dokumen Analisis Mengenai Dampak Lingkungan (AMDAL), sebagai berikut:

a. Kewajiban-kewajiban konsultan pembuat dokumen Analisis Mengenai Dampak Lingkungan (AMDAL), yaitu:

(1) Melaksanakan pekerjaan sesuai dengan ketentuan yang telah ditetapkan;

(2) Melaporkan pelaksanaan pekerjaan secara periodik kepada Pemrakarsa;

(3) Menyelesaikan dan menyerahkan pekerjaan sesuai dengan ketentuan;

(4) Menjaga keselamatan para pekerja dan menanggung segala resiko keselamatan kerja yang timbul selama pelaksanaan pekerjaan;

(5) Menjaga ketertiban lingkungan dalam pelaksanaan pekerjaan

(6) Memelihara bangunan selama 3 bulan setelah bangunan diserahkan kepada Pemrakarsa sesuai Berita Acara Serah Terima;

(7) Wajib mengasuransikan bangunan dari bahaya, seperti: kebakaran, huruhara dan bencana alam, 
sampai dengan 3 bulan setelah bangunan diserahkan oleh pihak Pemrakarsa;

(8) Apabila Konsultan lalai atau dengan sengaja tidak mengasuransikan bangunan dan terjadi suatu resiko seperti: kebakaran, huruhara dan bencana alam, maka pembangunan kembali menjadi tanggung jawab dan dilaksanakan penuh oleh Konsultan.

b. Hak-hak pembuat dokumen Analisis Mengenai Dampak Lingkungan (AMDAL), yaitu:

(1) Berhak mendapatkan datadata yang diperlukan dari dinas-dinas yang terkait;

(2) Berhak mendapatkan informasi dan keterangan dari pihak-pihak yang berkepentingan;

(3) Menerima pembayaran atas pekerjaan yang telah diselesaikan sesuai dengan ketentuan yang disepakati;

(4) Dilarang menyerahkan pelaksanaan pekerjaan, baik sebagian atau seluruhnya kepada pihak lain tanpa sepengetahuan Pemrakarsa. ${ }^{15}$

Selain kewajiban-kewajiban tersebut di atas, berdasarkan hasil wawancara dengan Robi menyatakan, bahwa:
Dalam pelaksanaannya konsultan pembuat dokumenAnalisis Mengenai Dampak Lingkungan (AMDAL) juga memiliki kewajiban, yaitu:

(1) Konsultan harus mengawasi kemajuan pelaksanaan dan mengambil keputusan yang tepat dan cepat agar batas waktu pelaksanaan minimal sesuai dengan jadwal yang ditentukan.

(2) Memberikan masukan pendapat teknis tentang penambahan atau pengurangan kegiatan yang dapat mempengaruhi biaya dan waktu pekerjaan serta berpengaruh pada ketentuan kontrak.

(3) Memberikan petunjuk, perintah sejauh tidak mengenal pengurangan dan penambahan biaya dan waktu pekerjaan serta tidak menyimpang dalam kontrak. $^{16}$

Sehubungan dengan hal tersebut di atas, berdasarkan data yang diperoleh dari wawancara diketahui bahwa konsultan pembuat dokumen Analisis Mengenai Dampak Lingkungan (AMDAL) dalam melaksanakan tugas-tugasnya sudah sesuai dengan tugas pokoknya dan sesuai dengan ketentuan yang telah diperjanjikan antar pihak, yaitu antara konsultan pembuat dokumen Analisis Mengenai Dampak Lingkungan

\footnotetext{
${ }^{16}$ Wawancara dengan Robi, Kepala Bagian AMDAL BLHD Kabupaten Belitung Timur, tanggal 28 Juli 2016.
} 
(AMDAL) dan pihak pemrakarsa. Namun tugas-tugas yang ada dalam peraturan perundang-undangan tidak seluruhnya dilaksanakan oleh konsultan pembuat dokumen Analisis Mengenai Dampak Lingkungan (AMDAL). Ada kewajiban-kewajiban yang masih menjadi tanggung jawab konsultan pembuat dokumen Analisis Mengenai Dampak Lingkungan (AMDAL), akan tetapi tidak dilaksanakan. Menurut Robi menyatakan, bahwa:

\begin{abstract}
Adapun kewajiban-kewajiban tersebut, antara lain: terkait dengan para pekerja, seperti: menjaga keselamatan dan menanggung resiko mereka dalam melaksanakan tugas, serta pemeliharaan bangunan pasca penyusunan atau pembuatan dokumen Analisis Mengenai Dampak Lingkungan (AMDAL). ${ }^{17}$
\end{abstract}

Lebih lanjut, menurut Robi menyatakan, bahwa "hal tersebut terjadi sebagai akibat dari ketidakjelasan perjanjian yang dibuat diawal oleh pemrakarsa dan konsultan pembuatan dokumen Analisis Mengenai Dampak Lingkungan (AMDAL)". ${ }^{18}$ Sebagai akibat dari awal perjanjian pihak Pemrakarsa kurang teliti, maka segala hal yang terjadi setelah pasca dikeluarkannya dokumen

\footnotetext{
${ }^{17}$ Ibid.

${ }^{18}$ Ibid.
}

Analisis Mengenai Dampak Lingkungan dalam bentuk izin usaha menjadi tanggung jawab pihak pemrakarsa. Sesuai dengan itu, menurut Saragih menyatakan, bahwa:

Konsultan AMDAL tidak memiliki kewenangan dan tidak bertanggung jawab terhadap dokumen AMDAL yang merupakan prediksi atas suatu kegiatan usaha yang telah dibuatnya apabila dokumen tersebut telah disetujui dan diterbitkan izin usaha oleh pemerintah. Jika terjadi pencemaran, yang memiliki tanggung jawab adalah pemrakarsa atau pemerintah yang telah menerbitkan izin usaha tersebut. ${ }^{19}$

Hal ini tentu akan membawa kerugian dari pihak pemrakarsa, sebab dengan menggunakan jasa konsultan pembuatan dokumen Analisis Mengenai Dampak Lingkungan (AMDAL), diharapkan dapat meminimalkan resiko kegiatan usaha, namun setelah kegiatan dilaksanakan, semua resiko yang telah diprediksi timbul menjadi permasalahan yang bersentuhan dengan lingkungan. Padahal, konsultan pembuatan dokumen Analisis Mengenai Dampak Lingkungan (AMDAL) merupakan pihak yang ikut dalam perencanaan atas suatu kegiatan, sehingga sewajarnya dapat dimintakan pertanggungjawaban secara hukum apabila

\footnotetext{
${ }^{19}$ Wawancara dengan Saragih, Konsultan AMDAL, tanggal 22 November 2016
} 
terjadi pencemaran lingkungan atas suatu

kegiatan.

Berdasarkan hasil data yang diperoleh, diketahui bahwa pelaksanaan tanggung jawab konsultan pembuatan dokumen Analisis Mengenai Dampak Lingkungan (AMDAL) di Provinsi Kepulauan Bangka Belitung hanya terbatas pada isi perjanjian. Pelaksanaan yang ada dalam peraturan perundang-undangan yang berlaku tidak semua dilaksanakan pihak konsultan pembuatan dokumen Analisis Mengenai Dampak Lingkungan (AMDAL), seperti pengawasan pasca dikeluarkannya dokumen Analisis Mengenai Dampak Lingkungan (AMDAL). Secara yuridis, konsultan pembuat dokumenAnalisis Mengenai Dampak Lingkungan (AMDAL) dapat dimintakan pertanggungjawabannya. Hal ini sesuai dengan prinsip strict liability, yang artinya apabila pencemar atau perusak tersebut adalah konsultan pembuatan dokumen Analisis Mengenai Dampak Lingkungan (AMDAL), maka konsultan pembuatan dokumen Analisis Mengenai Dampak Lingkungan (AMDAL) terbukti lalai dalam hasil kajian tentang Analisis Mengenai Dampak Lingkungan (AMDAL), sehingga ia masih memiliki tanggung jawab.

\section{PENUTUP}

\section{Kesimpulan}

a. Tanggungjawab konsultan dalam pembuatan Analisis Mengenai Dampak Lingkungan (AMDAL) diatur dalam Undang-Undang Nomor 32 Tahun 2009 Tentang Perlindungan dan Pengelolaan Lingkungan Hidup dan Peraturan Menteri Lingkungan Hidup Nomor 7 Tahun 2010 Tentang Sertifikasi Kompetensi Penyusun Dokumen Analisis Mengenai Dampak Lingkungan dan Persyaratan Lembaga Pelatihan Kompetensi Penyusun Dokumen Analisis Mengenai Dampak Lingkungan Hidup yang menentukan, bahwa konsultan pembuat Analisis Mengenai Dampak Lingkungan (AMDAL) bertanggung jawab atas semua data yang dibuatnya. Data yang dibuatnya tersebut adalah hasil Analisis Mengenai Dampak Lingkungan, yang laporannya berbentuk dokumen AMDAL.

b. Konsultan pembuat Analisis Mengenai Dampak Lingkungan (AMDAL) bertanggungjawab atas segala pembuatan dokumen Analisis 
Mengenai Dampak Lingkungan (AMDAL) perusahaan (pemrakarsa) yang menunjuknya. Tanggungjawab konsultan pembuat Analisis Mengenai Dampak Lingkungan (AMDAL) akan selesai sampai batas perjanjian dengan perusahaan pemrakarsa yang menunjuknya, yaitu ketika dokumen itu telah disetujui oleh pemerintah dalam bentuk telah dinilai oleh Komisi Penilai Analisis Mengenai Dampak Lingkungan (AMDAL).

\section{Saran}

a. Perlunya optimalisasi dari penegakan Undang-Undang Nomor 32 Tahun 2009 Tentang Perlindungan dan Pengelolaan Lingkungan Hidup dan Peraturan Menteri Lingkungan Hidup Nomor 7 Tahun 2010 Tentang Sertifikasi Kompetensi Penyusun Dokumen Analisis Mengenai Dampak Lingkungan dan Persyaratan Lembaga Pelatihan Kompetensi Penyusun Dokumen Analisis Mengenai Dampak Lingkungan Hidup, sehingga diharapkan pengaturan mengenai tanggungjawab konsultan pembuat dokumen Analisis Mengenai Dampak Lingkungan (AMDAL) dapat lebih baik;

b. Perlunya pengaturan yang lebih tegas, jelas dan komprehensif mengenai tanggungjawab dari konsultan pembuat Analisis Mengenai Dampak Lingkungan (AMDAL), sehingga konsultan pembuat Analisis Mengenai Dampak Lingkungan (AMDAL) tidak hanya bertanggungjawab atas penyusunan, tetapi juga bertanggungjawab apabila terjadi pencemaran terhadap lingkungan.

\section{DAFTAR PUSTAKA}

Addinul Yakin. 1997. Ekonomi Sumber Daya dan Lingkungan, Teori dun Kebijaksanaan Pembangunan Berkelanjutan. Jakarta Akademika Presindo. Jakarta.
Ahmadi. "Walhi Babel Soroti Amdal Penambangan Pasir Kuarsa". http://m.antarababel.com/berita/9847/ walhibabelsorotiamdalpenambangan pasirkuarsa. Diakses pada hari Jum'at tanggal 24 April 2015 pukul 21:00 wib.

Agenda 21 Sektoral. 2000. Agenda ENERGI Untuk Pembangunan 
Kualitas Hidup Secara

Berkelanjutan. Proyek Agenda 21

Sektoral Kerjasama Kantor Menteri

Negara Lingkungan Hidup dengan

UNDP. Jakarta.

Andi Hamzah. 1986. Kamus Hukum. Ghalia Indonesia. Jakarta.

A. Sonny Keraf. 2006. Etika Lingkungan. Penerbit Buku Kompas. Jakarta.

Bahder Johan Nasution. 2008. Metode Penelitian Ilmu Hukum.Cetakan Pertama. CV. Mandar Maju. Bandung.

Daud Silalahi. 2001.Hukum Lingkungan dalam Sistem Penegakan Hukum Lingkungan Indonesia. Alumni. Bandung.

Departemen Pendidikan Nasional. 2008. Kamus Besar Bahasa Indonesia. Pusat Bahasa Departemen Pendidikan Nasional. Jakarta.

Emil Salim. 2010.Ratusan Bangsa Merusak Satu Bumi. Penerbit Buku Kompas. Jakarta.

Eri Triana Sari. 2009.Tanggungjawab Konsultan dalam Pembuatan Analisis Mengenai Dampak Lingkungan dan Akibat Hukumnya (Studi Kasus di CV. Daya Cipta Mandiri). FH Universitas Semarang. Semarang.

Ginandjar Kartasasmita. 1997. Administrasi Pembangunan: Perkembangan Pemikiran dan Praktiknya di Indonesia. Pustaka LP3ES. Jakarta.
Haerudin R. Sadjudin. Panduan Penegakan Hukum dalam penyelamatan Hutan. Inform (Indonesia Forest and Media). Jakarta.

Helmi. 2012. Hukum Perizinan Lingkungan Hidup. Sinar Grafika. Jakarta.

Magister Ilmu Hukum. 2008. Pedoman Tesis Magister Ilmu Hukum. Program Pascasarjana Program Magister Ilmu Hukum Universitas Jambi. Jambi.

M. Saifudin. 2013. “Tanggung Jawab Konsultan AMDAL dalam Pembuatan Analisis Mengenai Dampak Lingkungan”. Makalah. Fakultas Hukum Universitas Mulawarman.

Republik Indonesia. Undang-Undang Nomor 32 Tahun 2009 Tentang Perlindungan dan Pengelolaan Lingkungan Hidup. Lembaran Negara Republik Indonesia Tahun 2009 Nomor 140, Tambahan Lembaran Negara Republik Indonesia Nomor 5059.

Sahuri Lasmadi. 2009. Bahan Ajar Hukum Lingkungan Lanjutan. Program Megister Ilmu Hukum Fakultas Hukum Universitas Jambi. Jambi.

Salim, H.S. Dasar-Dasar Hukum Keluitanan. Edisi Revisi. Sinar Grafika. Jakarta.

Zaenal Bahri. 1993. Kamus Umum: Khusus Bidang Hukum dan Politik. Angkasa. Bandung. 